\title{
MARKET TRENDS AND TREPIDATIONS: A STUDY ON RAINBOW CAPITALISM IN INDIA
}

\author{
Anahita Kapoor \\ Pathways School Gurgaon, Haryana \\ DOI: 10.46609/IJSSER.2020.v05i05.018 URL:https://doi.org/10.46609/IJSSER.2020.v05i05.018
}

\begin{abstract}
It is an encouraging development that the LGBTQ community has seen an increase in their rights and made progress towards equal treatment. Along with this development, they have seen an increase in purchasing power and participation in the economic and social system. Rainbow capitalism emerged as a method of integrating the community into the market economy, when corporations realized that it is profitable to be inclusive in marketing and advertising, creating a whole host of new avenues for expansion. Activists in India and across the world have expressed concern that rainbow capitalism has increased visibility, but the profit motive does not contribute to an increase in rights or awareness of structural, institutional and socio economic issues that the community continues to face especially in a developing country like India. This paper will examine the emergence of rainbow capitalism in India, especially in light of the decriminalization of Section 377, and highlight the critiques by activists and possible counteractions. The paper will conclude with an emphasis on the sociological effects and drawbacks of rainbow capitalism in the Indian context.
\end{abstract}

Keywords: Rainbow capitalism, LGBTQ community, LGBT in India, Basic rights

\section{INTRODUCTION}

Rainbow capitalism is the incorporation of the LGBT movement and sexual diversity to capitalism and the market economy, viewed especially in a critical lens as this incorporation pertains to the LGBT, Western, white, and affluent, upper middle class communities and market (Exall, 2015). In the past decades, the LGBTQ community through mass movements have managed to make a great deal of progress in obtaining equal rights in several countries, ranging from de-criminalization of homosexuality to marriage equality. This has led to the community being considered as equal members of society, and has also had the consequent effect of 


\section{International Journal of Social Science and Economic Research}

ISSN: $2455-8834$

Volume: 05, Issue: 05 "May 2020"

increasing their purchasing power (Exall, 2015). Rainbow capitalism is a targeted inclusion of the gay community which has acquired sufficient purchasing power (referred to in this context as pink money) to generate a market focused specifically on them (Exall, 2015). Examples of such targeted inclusion are bars and nightclubs, LGBT tourism, or specialized culture consumption (Rahaman, 2019).

The increased participation of the LGBTQ community in society has been taken advantage of by capitalist exploitation, or the co-optation of these issues into the market economy. Although this has increased awareness in some ways and put important issues in the mainstream, it has also raised valid concerns that the support is only in service of tokenism to make a profit and is a form of appropriation. In the wake of the decriminalization of homosexuality in India by striking down Section 377, there has been a rise of capitalist exploitation of LGBTQ+ issues.

This paper will examine the history of LGBTQ+ movements and corresponding market events in India, tracing the rise of rainbow capitalism and the critiques of the same. The paper will further examine the sociological effects of rainbow capitalism, and the importance of awareness without profit motivated exploitation.

\section{BACKGROUND}

The Indian queer community has a newfound economic autonomy post the decriminalization of this archaic Section 377 (Watta, 2019). With a more acceptance and increased visibility, at least in urban spaces, the queer community has seen an increase in employment, primarily selfemployment and freelance ventures (Watta, 2019). The rise in pink capitalism can be seen in three phases. The first was the underground phase, functioning covertly in the form of gay bars and print magazines under fascist regimes (Watta, 2019). Later followed the community building phase that kick started collective liberation, and also led to a vehement increase in the opposition. With the dawn of the new millennium we move into a phase that works into integration of media culture and several subcultures which is driven by differentiated agendas but arbitrarily driven by same belief in human rights and self-expression (Watta, 2019).

Especially post the milestone of decriminalization in India, the fashion, beauty, and advertising industries have been thriving through rainbow capitalism. In the West, this is now reflected in the mainstream commercial market. Shoes, bags, clothes and accessories in the vibrant colours of the rainbow have flooded markets in Japan and China and these products are now slowly finding their way into India too (Sarkar, 2018). Activists point out that the queer 'merchandise' often are stolen of queer artists and manufacturing is done in sweatshops in third world countries (Watta, 2019). 


\section{International Journal of Social Science and Economic Research}

ISSN: $2455-8834$

Volume: 05, Issue: 05 "May 2020"

In 2009 when the LGBT community first won a victory with the Delhi High Court decision decriminalising homosexuality there were only a few corporate supporters, like Absolut vodka, which is a global supporter of LGBT issues, and, remarkably, Amul, which has long had a lowkey but firm commitment to progressive topical issues in its billboards with the Amul girl (Doctor, 2019).

However, this judgment was overturned in the Supreme Court in 2013, when Section 377 was reinstated. Notably, it was only Amul who was the major corporate player that expressed sorrow for this outcome through an advertisement (Doctor, 2019). Therefore, the history of pride in India has come along with concerns about market structures, and a great deal of skepticism from queer activists that true LGBT freedom is at odds with the monopoly of corporate interests and the hegemony of pro-capitalist thought (Exall, 2015).

A primary concern for activists is that such corporate campaigns are hollow. They tackle queer issues at the surface level, but fail to address the deeper problems that lie within (Watta, 2019). Majority of the campaigns, portray this issue not as a tangible social marginalization but as a celebratory occasion (Watta, 2019; Mukherjee, 2019). The prevailing view is that what is required is deeper understanding and addressal that does not celebrate a symbolic victory, but highlights the continued issues that are faced by the LGBTQ community. Furthermore, campaigns like these portray the movement as divorced from politics (Watta, 2019). The slogans limit to expressionism, and several problems like hate crimes, conversion therapies, forced marriages, corrective rape etc are not addressed (Watta, 2019). Activists state that these 'buzz kill' truths are done away with and the entire LGBTQIA+ population of India becomes one hypersexual demographic (Watta, 2019).

In urban India, where social media and corporate initiatives have created increasing awareness of LGBT rights, the scenario looks more upbeat for gay men than for transgender people or lesbian women (Patel, 2016). While urban LGBT voices that are heard through several online and realworld platforms form an important part of LGBT activism, these expose only a small part of the diverse challenges faced by the community (Patel, 2016). Especially in India, there is a long road ahead with respect to equal treatment of the community, at a very fundamental level. There is discrimination in the workplace, a disproportionate number of the LGBTQ community who are affected with HIV, and a disproportionate number of them living in poverty. Corporate campaigns only cater to the urban middle and upper middle class (Mukherjee, 2019). Therefore, it is key to explore alternatives, which focus on how to be supportive without being exploitative, and address the myriad of issues.

\section{DISCUSSION}




\section{International Journal of Social Science and Economic Research}

ISSN: $2455-8834$

Volume: 05, Issue: 05 "May 2020"

Market trends can influence society in terms of increasing awareness about such issues. LGBTQI activist Delfina, who works with Chennai based NGO Nirangal, claimed, "brands may use the 'pride' to market their products but then it opens a window for people unaware of the community to engage in the conversation. Although we get support from the heterosexual community, there are other ignorant people who might wake up to pride making its way to mainstream commodity market and acknowledge it. And instead of criticizing brands for capitalising on rainbow, we can ask them to translate this into reality and provide employment for the community" (Sarkar, 2018).

However, this appropriation is only at the surface level which serves to increase insensitivity in the long run, and a lack of any structural changes. For example, the transgender rights bill has been criticized for being grossly inadequate (Sanghvi, 2019). It has been noted that corporates have embraced the inclusion of the community because it was economically expedient (Bloomberg, 2018). For example, a 2018 report sponsored by Accenture, the Brunswick Group and Thomson Reuters, among others, found inclusive policies were linked to greater GDP per capita, competitiveness, entrepreneurship, urban development, talent retention and a better national reputation that could bring in additional direct investment (Bloomberg, 2018). India was losing around $1.4 \%$ of its national output because of Section 377, according to calculations by Lee Badgett, an economics professor at the University of Massachusetts, Amherst. That means discriminating against the LGBTQIA+ community was costing India around US $\$ 26$ billion a year (Bloomberg, 2018; Mukherjee, 2018).

Activists have rightly pointed out that viewing the issue in this way does not lend to a genuine discussion or reform on the issues and hardships that continue to plague the community, instead trying to create a homogenized message (Rahaman, 2019; Watta, 2019). This attitude could be seen in all the corporate messages that flooded public media after the Supreme Court's second judgment last year that finally, definitively, decriminalized homosexuality in India (Doctor, 2019). From Amul to Bata, Indigo to L'Oreal the message was that this verdict was a victory not for just the LGBT community, but for all. Cab service Uber painted the routes on the map with rainbow snakes and Ola's app reflected rainbow colours (Doctor, 2019).

However, actual measures to help the community are few and far between. Transport giant Uber, which has an "Uberpride" community formed to promote LGBTQI inclusion and diversity, has hired a transgender Rani Kinnar as its cab driver (Sarkar, 2018). Their food delivery platform Uber Eats has employed another transgender Preethisha. Uber's immediate competitor Ola had provided employment to MBA graduate Meghna Sahoo as their first transgender cab driver partner earlier this year (Sarkar, 2018). These remain stray examples- for example, the head of marketing at consumer goods company Patanjali - one of India's largest private sector 


\section{International Journal of Social Science and Economic Research}

ISSN: $2455-8834$

Volume: 05, Issue: 05 "May 2020"

employers, stated that the idea of rights for gay employees at the company was a "nonsensical question," post the 377 ruling (Mukherjee, 2019).

LGBT workers are more than twice as likely to be bullied as straight workers, discrimination overt or covert is still rife and are far from having workplaces that are safe and welcoming (Exall, 2015). Even if hired, majority of them keep their identity secret and stringent dress codes, binary washrooms contribute to the erasure of these identities in public spaces (Watta, 2019). There is no stringent corporate policy against harassment based on sexual orientation and gender identity (Watta, 2019).

Further, it is pertinent to note that those arguing before the Supreme Court against the decriminalization of homosexuality in India especially in 2013, argued that the LGBT movement was a corporate conspiracy to subvert traditional values for the benefit of marketing to rich gay consumers (Doctor, 2019). They point to corporate support of LGBT issues as a sign of the conspiracy against them- this turned out to be an effective argument with the judges (Doctor, 2019).

In addition, rainbow capitalism of this sort completely ignores the poor and rural India who are not consumers of the products these companies make. In rural areas, secret honour killings are planned so that the only way for a young gay man to survive is to run away in the cover of the night to some city, with no money or social support (Patel, 2016). In other parts, lesbian women are subjected to family-sanctioned corrective rapes, which are often perpetrated by their own family members (Patel, 2016). While there are cafés and clubs in the metropolis that specifically cater to the community, they are, by and large, reserved for the affluent (Mukherjee, 2019). A right to exercise your identity cannot be restricted to those who have money (Mukherjee, 2019). While brands that recognize queer identities are supremely important - especially because gender performance is inextricably linked with material culture - being queer is more than a lifestyle choice (Mukherjee, 2019).

Considering TV and movies are accessible to even rural populations where social media has not yet penetrated, these could prove to be the most effective tools in redefining the roles and attitudes of families through programmes and stories that not only educate and enlighten but also relay LGBT experiences in authentic and varied voices (Patel, 2016). It is an encouraging sign that schools and colleges have begun to take up institutionally approved LGBT activism as well (Patel, 2016).

\section{CONCLUSION}




\section{International Journal of Social Science and Economic Research}

ISSN: $2455-8834$

Volume: 05, Issue: 05 "May 2020"

The sociological impact of market economy trends, is therefore important to consider. While increasing visibility, rainbow capitalism does not seem to do much else in the way of increasing awareness and sensitivity towards LGBTQ+ issues in India. The visibility through activism or through these campaigns is of no use if it cannot be transformed into everyday basic rights (Mukherjee, 2019). Dr. Gautam Bhan, a researcher who studies urban poverty and inequality, spent 14 years fighting to decriminalize homosexuality. He spoke in a conference about how urban spaces make it impossible for same-sex couples to own their own house together, start a family and live a normal life (Mukherjee, 2019). Without legalizing gay marriage, there is no way of realizing the abstract freedom decriminalizing homosexuality gives us into material reality. Even though LGBTQIA+ people have the freedom to love whoever they want on paper, in reality, they cannot do so (Mukherjee, 2019).

Paradoxically, increasing awareness about LGBT rights was making clear this lack of affluence. In the past LGBT people who could resist the pressure to get married, and lead their own lives, had to be fairly affluent to do so (Doctor, 2019). Well-off and hence more secure LGBT people were more likely to identify as such (Doctor, 2019). In India, most cannot identify or are excluded upon doing so, resorting to sex work and other such occupations. There is a danger that pink capitalism, paraded under consumerism and elitism, gets mistaken for rights, and ignoring the psychological issues and institutional barriers (Mukherjee, 2019). It happened in the West; it happened with marketplace feminism, and there is increasing proof that it is happening here in India (Mukherjee, 2019).

Therefore, it is important to recognize that the profit motivated methods of capitalism are not in consonance with a deeper understanding of socio economic and rights based issues, especially in India where the majority of the population is not from the urban, affluent class. India is a vast and diverse country and attitudes towards this subject and experiences of LGBTQ individuals vary vastly. The disparity between urban and rural India, language, caste, class and gender add further complexities to understanding this topic more fully (Patel, 2019), and consumerism must not overshadow and subsume these complexities.

\section{REFERENCES}

Bloomberg, (12 September 2018), 'Pink dollar' to boost Indian economy after gay sex legalized', Livemint, https://www.livemint.com/Politics/SqpKWIyBy5VeGBOEqIbQuL/Pinkdollar-to-boost-Indian-economy-after-gay-sex-legalize.html

Doctor, V, (8 June 2019), 'Understanding LGBT Movement through currency notes', The Economic Times, https://economictimes.indiatimes.com/currencies-commerce-and-theimportance-of-acceptance/articleshow/69695750.cms?from=mdr 
Exall, M, (25 June 2015), 'Resisting the Rise of Pink Capitalism', The Morning Star, https://web.archive.org/web/20160302140229/http://www.morningstaronline.co.uk/a6d97-Resisting-the-rise-of-pink-capitalism

Mukherjee, S, (25 June 2019), 'Corporate Investment in Pride Increases Visibility, But Doesn't Expand Rights', The Swaddle, https://theswaddle.com/corporate-investment-in-prideups-visibility-but-doesnt-expand-rights/

Patel, R, (27 August 2016), 'Being LGBT in India: Some home truths', Livemint, https://www.livemint.com/Sundayapp/sAYrieZdZKEybKzhP8FDbP/Being-LGBT-inIndia-Some-home-truths.html

Patel, Z, (17 May 2019), 'The long road to LGBT equality in India', UNDP India, https://www.in.undp.org/content/india/en/home/blog/lgbtequalityindia.html

Rahaman, N, (19 February 2019), 'Rainbow Capitalism in India', Wrytin, https://wrytin.com/nasiburrahaman/rainbow-capitalism-in-india-jsbyz311

Sarkar, A, (14 September 2018), 'Anger at big brands capitalising on Rainbow Pride in India, but is it misdirected?', The New Indian Express, https://www.newindianexpress.com/nation/2018/sep/14/anger-at-big-brands-capitalisingon-rainbow-pride-in-india-but-is-it-misdirected-1871904.html

Sanghvi, M, (26 June 2019), 'History of the pride movement in India', Deccan Herald, https://www.deccanherald.com/specials/history-of-the-pride-movement-in-india742950.html

Watta, A, (26 June 2019), 'Is Rainbow Capitalism Truly Queer Liberation', Gaysi, http://gaysifamily.com/2019/06/26/is-rainbow-capitalism-truly-queer-liberation/ 